\title{
Ecos do narrador benjaminiano no filme O Labirinto do Fauno: uma (re)significação da morte pela fidelidade ao Événement
}

\author{
Giuliano Hartmann* \\ Marisa Corrêa Silva**
}

\begin{abstract}
Resumo: $O$ narrador benjaminiano é a presença condenada ao esvaziamento que faz parte de uma tradição já problematizada; é o eco que, ao longo dos tempos, instilou valores e regulou conceitos de vida. O contemporâneo apresenta-o em constante exílio, corrompida sua sabedoria: viver é banal e morrer já não produz nem faz sentido. Nesse contexto, literatura e cinema transformam a oposição de vida e de morte em um dístico opaco e relativizado: viver é o agora e a morte torna-se um signo plano, um simulacro. O presente trabalho objetiva refletir acerca da questão da representação da morte pela perspectiva do narrador em O Labirinto do Fauno (2006), voz onisciente que apresenta Ofélia, imersa em um universo de opressão e sombra, personagem que tem sua perene existência (re)simbolizada no momento em que viver não significa nada e morrer resgata valores, transformando-se em imortalidade no sentido preconizado por Alain Badiou, de fidelidade ao Acontecimento (événement).
\end{abstract}

Palavras-chave: $O$ narrador. Cinema. Morte. Contemporâneo. Walter Benjamin.

\section{ALGUMAS CONSIDERAÇÕES SOBRE LITERATURA E CINEMA}

A literatura pode estabelecer, entre outras relações, a refratação dos lados mágico e lúdico das culturas e das sociedades no que tange o real, uma relação intrínseca e frequentemente marcada pela transcendência ou distorção da pragmática cotidiana, mesmo em textos que aparentemente possuam caráter "realista". O mundo da ficção é uma dimensão em suspenso, está além das expectativas, se amarra à realidade, e, ao mesmo tempo a repele: sua relação com o mundo real se pauta na dialética entre objeto e representação, processo de interação entre dois universos, 0 real e o ficcional, atestando que "o homem é um ser complexo, percebe e recria o

* Mestre em Estudos Literários (UEM). Doutorando pela Universidade Estadual de Maringá - UEM. E-mail: giulihartmann@gmail.com

** Pós-doutora pela Rutgers State University of New Jersey (USA). Doutora em Letras pela Universidade Paulista Júlio de Mesquita Filho. Professora associada no Departamento de Letras da Universidade Estadual de Maringá (UEM). E-mail: mcsilva5@uem.br 
mundo pela sintaxe dos sentidos, sentimentos razão e emoção" (PALMA, 2004, p.08), fato que reitera a ideia de que a representação do mundo pela arte literária é tão complexa e dual quando o é o próprio ser humano, forjado na incerteza e incompletude de ser e estar no mundo sem nenhuma garantia. Assim, conforme atesta Palma, "o legado da arte literária é construção cultural sólida, rica; este saber acumulado das experiências humanas através do tempo não se degrada nem se banaliza ao ser tomado como objeto de leitura dialógica" (2004, p.09), o saber literário se eterniza à medida que se atualiza e se abre para o novo, da mesma forma que se permite lançar olhares em direção às outras artes, na busca de estabelecer diálogos possíveis visando primor estético e a reflexão acerca de si.

Ora, ao estabelecer diálogos possíveis e fecundos com as outras artes, a literatura se aproxima do cinema que, por excelência, é a arte em e do movimento, unindo características das artes cênicas (do movimento) com a narrativa e a poesia (artes em movimento); a obra cinematográfica bem sucedida vivifica e desestabiliza a fria realidade. Palma assevera que "as categorias ficcionais, as temáticas, os debates de ideias, as técnicas de produção e criatividade artística são elementos estruturadores do discurso literário, tanto quanto do cinematográfico" (2004, p.0708), ou seja, ambas as artes comungam, em alguns aspectos, da mesma fonte. Literatura e cinema dialogam no contexto da contemporaneidade (um tempo de turbulências e transformações), inseridas nos fenômenos da Indústria Cultural e da Cultura de Massas e suas acaloradas discussões, buscando uma forma de representar e de estarem representadas em uma espécie de jogo de espelhos, numa relação dialógica cujos desdobramentos transitam entre mundos possíveis, que ora se superpõem, ora intersectam, ora se entrechocam em tensões insolúveis, ora deságuam em paradoxos.

$\mathrm{Se}$, de um lado, literatura e cinema comungam de um mesmo ideal artístico, a recuperação do mundo pelo viés representativo, de outro, dentro do próprio bojo literário, o cinema delimita seu campo de diálogo evidenciando, na maioria de suas produções, uma maior afinidade com o romance e sua capacidade de arte mimética e insólita, ambos se afinando pelo aspecto essencial do romance que é a estrutura, seus componentes e possíveis desdobramentos narrativos. Um exemplo de possível exceção seria o filme Kooyanisqatsi (1982), cuja composição se aproxima mais da poesia. Tanto o romance quanto o cinema possuem, em sua forma intrínseca, o tempo, o espaço, suas personagens, a focalização e a figura - antes suprema, hoje problemática - do narrador. Observando de perto esse esquema estrutural, deter-nos-emos em um elemento: o "eu" que fala e que assume a postura de detentor do conhecimento parcial/total da ação a ser desenvolvida, ou seja, o narrador.

O presente artigo propõe uma reflexão acerca da presença do narrador, não enquanto elemento estrutural, mas como representante milenar de uma tradição quase extinta. $O$ que se pretende, especificamente, é localizar ecos do narrador benjaminiano no filme $O$ Labirinto do Fauno (2006) do diretor Guillermo Del Toro, bem como aventar a hipótese desse narrador funcionar estruturalmente como porta-voz da fidelidade ao Evento e tendo como foco a figura de Ofélia, personagem dual que transita em um mundo de sombras e fantasia, fronteira entre vida e morte. 


\subsection{A imortalidade segundo Alain Badiou}

O filósofo francês de origem marroquina parte do conceito de Spinoza da "perseverança do ser" (2001, p. 46) para propor um conceito de imortalidade baseado na superação do homem-animal, do homem-biológico, comprometido com a própria sobrevivência e a de sua espécie. A forma de transcender o mecanismo biológico, na proposta de Badiou, é a "fidelidade ao Evento" (événement, que traduzimos por "Evento", embora haja traduções brasileiras que optam pelo termo "Acontecimento").

O Evento é a irrupção histórica de uma nova organização do mundo: de uma lógica que atravessa as possibilidades anteriores e que instaura um novo mecanismo de inclusão/exclusão. Um exemplo clássico do Evento, segundo Badiou (2009), é o surgimento do cristianismo paulino, criando a comunidade dos crentes, numa terceira via que desorganiza a oposição binária até então considerada a única possível, entre o pensamento romano (baseado na lei, na jurisprudência) e o judaico (baseado na tradição). A fidelidade dos cristãos primitivos ao Evento-cristianismo levou muitos deles à morte, mas essa mesma fidelidade é o que transforma o cristão sacrificado em imortal, uma vez que o faz transcender a condição de máquina biológica. A morte desse cristão não é mais apenas a interrupção do processo de vida, mas um dado físico que não altera sua condição de imortal, assumida no instante em que ele, conscientemente, escolhe ser fiel ao Evento.

Esse pensamento retoma a metafísica, mas, paradoxalmente, acaba por introduzi-la nas escolhas cotidianas do mundo em que vivemos, e não mais a consagra à esfera do numinoso ou do impalpável. A irrupção do Evento exige uma tomada de posição imediata e grande cuidado para que o indivíduo diferencie o Evento verdadeiro do falso - cujo exemplo é a ascensão do nazismo. Segundo Badiou (2009), o discurso e a aparência do nazismo copiavam a estrutura do verdadeiro Evento, mas se diferenciavam dele porque, ao contrário dele, não vinham para desmontar as lógicas vigentes, propondo alternativas até então "impossíveis", mas sim para cumprir radicalmente o desejo não enunciado das classes dominantes: extirpar da sociedade alemã (e europeia) o Outro que a impedia de realizar seu potencial pleno (encarnado no judeu tal como imaginado pelos anti-semitas) e destruir o Comunismo. Um Evento jamais vem para conservar o que existe, portanto o nazismo não poderia jamais se enquadrar em sua definição.

Mais adiante em nossas considerações, retornaremos ao Evento dentro do filme de Del Toro. Antes, porém, é imprescindível pensar a questão do narrador benjaminiano na contemporaneidade e em outros contextos que não o do gênero romance.

\section{2. a questão do narrador e sua relação com a tradição}

A vivência contemporânea ocorre num tempo cronológico, não permitindo o resgate de nada e, conferindo ao instante um aspecto polivalente: o tudo e o nada dividem o mesmo espaço. Entenda-se aqui o termo contemporâneo conforme a proposição de Giorgio Agamben: "[...] uma singular relação com o próprio tempo, que 
adere a este e, ao mesmo tempo, dele toma distâncias; mais precisamente, essa é a relação com o tempo que a este adere através de uma dissociação e um anacronismo" (AGAMBEN, 2009, p.59), ou seja, a incapacidade de se concatenar com seu próprio tempo, já que se trata do próprio percurso histórico em andamento e por isso, impossibilitado de uma rotulação satisfatória. Enquanto terminologia teórica, torna-se uma forma menos instável e controversa de se tratar o tempo presente e suas tentativas de aderência ao prefixo "pós" em detrimento de um presente que resiste a rótulos classificatórios.

Assim, o contemporâneo (visto no corpo desse artigo como sinônimo de pósmodernismo, pós-moderno e pós-modernidade, procurando evitar uma discussão acalorada e em andamento) aparece sistematizado por meio de um elenco que inclui: ruptura, esfacelamento de paradigmas, destruição de valores que distanciam o erudito e o popular (ou que os aproxima e os perpassa), o questionamento por excelência, a relativização de paradigmas, a dessacralização dos cânones, fazendo desmoronar a ideia que se tem acerca dos valores de cultura e tradição, sendo a arte a primeira a sentir, absorver e refletir tal fenômeno. Nessa esteira, segundo Eagleton:

Pós-Modernismo é um estilo de cultura que reflete um pouco essa mudança memorável por meio de uma arte superficial, descentrada, infundada, autoreflexiva, divertida, caudatária, eclética e pluralista, que obscurece as fronteiras entre a cultura elitista e a cultura popular, bem como entre a arte e a experiência cotidiana (EAGLETON, 1998, p.07).

Nesse bojo, a literatura "contemporânea não será necessariamente aquela que representa a atualidade, a não ser por uma inadequação, uma estranheza histórica que a faz perceber as zonas marginais e obscuras do presente, que se afastam de sua lógica" (SCHOLLHAMMER, 2009, p.10). Na mesma linha, o cinema contemporâneo relativiza a tradição e a secularização da arte e de seus valores sociais e humanos. Há uma interrogação que circunda a arte e sua relação com o presente, ela se ancora no estranhamento, na reinvenção e no abandono das formas e na ressignificação do signo enquanto linguagem. Dessa forma, literatura e cinema se coadunam, ambas as artes pautadas no ato de narrar, dependentes do movimento, mas que, mesmo tributárias da tradição narrativa, parecem decretar a falência dessa tradição quando comparadas às grandes narrativas do passado. No "hoje" o insólito parece substituir o alento que vinha da experiência vivificada no passado pela voz de um narrador marcado pela experiência. A tradição está morrendo e, junto com ela, seu narrador, não aquele do universo romanesco, mas o que perpassou o tempo e o espaço e se perdeu com o advento do estilo de vida capitalista e com a supremacia do narrador do romance e a reinvenção da narrativa com o silenciamento do pós-guerra.

Esse narrador da tradição (distinto, portanto, do narrador enquanto elemento operador na narratologia), segundo Walter Benjamin (1892-1940), é uma figura que, ao ter seu significante pronunciado no hoje da contemporaneidade, parece vazio de significado, é algo distante, irrecuperável, aniquilado no tempo, e "por mais familiar que seja seu nome, o narrador não está de fato presente entre nós, em sua atualidade viva. Ele é algo de distante, e que se distancia ainda mais" (BENJAMIN, 1994, p.197). 
O narrador sucumbe porque seu valor se perdeu, as sociedades (pós)modernas relativizam o conceito e o valor da tradição, do resgate da experiência humana, e, as formas de se repassar essa experiência. O que se tem na atualidade, via perspectiva benjaminiana nesse sentido, "é a experiência de que a arte de narrar está em vias de extinção" (BENJAMIN, 1994, p.197), e isso é sentido desde o contexto histórico no qual Benjamin escreveu - o ensaio é datado de 1936 - devido ao fato de que não há o que contar, não existe mais o legado da experiência a ser passado, há somente o aspecto insólito de se estar no mundo. O homem do pós guerra (e aqui trata-se da I Guerra Mundial, entre 1914 e 1918) foi atravessado por um fenômeno que alimentou a extinção do narrador: ele perdeu sua capacidade comunicativa. Segundo Benjamin,

com a guerra mundial tornou-se manifesto um processo que continua até hoje. No final da guerra, observou-se que os combatentes voltavam mudos do campo de batalha não mais ricos, e sim mais pobres em experiência comunicável. E o que se difundiu depois dez anos depois, na enxurrada de livros sobre a guerra, nada tinha em comum com a experiência transmitida de boca em boca. (BENJAMIN, 1994, p. 198).

Dessa forma, a voz que exaltava os grandes feitos e as glórias de se viver em plenitude não atinge mais seus ouvintes, seja porque o som que sai não é alto o bastante, seja porque aqueles que ouviam não se dispõem mais a escutar aquilo que não é mais legitimamente seu.

O conceito de "modernização", no sentido proposto por Marshall Berman (1986, p. 16) como processo permanente, reinstaurado a curtos intervalos de tempo, sobrevalorizado, que tem o condão de tornar toda e qualquer tradição disfórica, aliado à ausência da experiência e do ter o que contar, paulatinamente decretaram o fim da existência do narrador, presença prenhe de representação e perpetuação do conhecimento e tradição. Segundo Benjamin (1994, p. 198), mesmo a concepção primordial do que significa ser um narrador se perdeu, não cabendo mais nem a experiência do viajante e as aventuras de terras distantes, nem a do sedentário que tem toda sua vida de trabalho para contar. Nem mesmo o narrador por excelência, que traz em si os dois veios narrativos, sobreviveu: esvaiu-se no tempo e no espaço. Não existe mais significação no ato de narrar, não se conhece mais a natureza latente da verdadeira narrativa, em seu lugar resta o vazio. Quando remonta à antiga narrativa, Benjamin afirma que: "ela tem sempre em si, às vezes de forma latente, uma dimensão utilitária. Essa utilidade pode consistir seja num ensinamento moral, seja numa sugestão prática, seja num provérbio ou numa norma de vida - de qualquer maneira, o narrador é um homem que sabe dar conselhos" (BENJAMIN, 1994, p.200).

Havia, pois, uma sabedoria tecida nas palavras desse narrador que contava histórias, desse sujeito que destilava conhecimento à medida que o seu verbo sempre tinha algo a acrescentar, pois, "o conselho tecido na substância viva da existência tem um nome: sabedoria. A arte de narrar está definhando porque a sabedoria - o lado épico da verdade - está em extinção" (BENJAMIN, 1994, p.200-201). Há, assim, nas palavras de Benjamin uma profunda melancolia ao atestar o fim da grande narrativa e a substancial ausência de experiência e conhecimento a ser passado, ou seja, a magia está perdida diante dos novos simulacros de existência. 


\subsubsection{O narrador e as outras narrativas: uma relação de assimetria}

Em termos benjaminianos, se o fim da guerra, a ausência do que contar, a falta de experiência e a impossibilidade de um conselho prático, gradativamente extinguiram o narrador do seio social no contemporâneo, cabe ao romance também sua parcela de culpa. Há nele uma frustrada tentativa de resgate desse "algo faltante" que se perdeu, que atualiza uma tradição quase esquecida, ao mesmo tempo em que dela escarnece. Ora, "o primeiro indicio da evolução que vai culminar na morte da narrativa é o surgimento do romance no início do período moderno" (BENJAMIN, 1994, p.201), ou seja, o romance está fatalmente amarrado ao livro, ao papel e sua difusão no mundo social enquanto que "a tradição oral, patrimônio da poesia épica, tem uma natureza fundamentalmente distinta da que caracteriza o romance" (BENJAMIN, 1994, p. 201).

O romance é fechado em si mesmo, está sozinho no mundo, não se vincula à tradição oral, não se realiza no ato de repassar e contar a experiência, permanece inalterado enquanto que no escopo da tradição, "o narrador retira da experiência o que ele conta: sua própria experiência ou a relatada pelos outros" (BENJAMIN, 1994, p.201). Há, no ato criador do romancista, o amargo da solidão, de imaginar vidas e falsas experiências, criar um mundo que não é o seu e também não é de ninguém, apenas um universo a parte, "o romancista segrega-se. A origem do romance é o individuo isolado, que não pode mais falar exemplarmente sobre suas preocupações mais importantes e que não recebe conselhos nem sabe dá-los" (BENJAMIN, 1994, p.201). A narrativa do romance busca o limiar do que é ou do que pode ser a vida, mas só existe no papel, tentando exaustivamente decantar em suas páginas um sentido para acontecimentos fatídicos e para outras tantas perguntas que surgem como incógnitas sem respostas: há, em suas linhas, apenas sugestão e sedução. Assim, o narrador tradicional vai-se esvaindo à medida que narrar seus feitos ou os dos outros nada tem a acrescentar, não havendo mais por que importar-se com a experiência coletiva: no reino do "agora", impera o indivíduo em sua acepção mais plena, ou seja, isolado, sozinho.

Na base dessa crise pautada entre sobrevivência e morte, ou seja, no fato de que o narrador da tradição está no fim e cabe ao romance uma grande parcela da culpa, há ainda outro elemento que, além de afirmar a morte do narrador, desestabiliza também o próprio romance: "essa nova forma de comunicação é a informação" (BENJAMIN, 1994, p. 202). Sempre dada como algo pronto para ser rapidamente digerido, ela (a informação) não vive além de seu próprio momento, é perene e não leva ao questionamento ou à contestação, mas elege e é eleita por seu público, vigora na grande massa. Benjamin assevera que:

O saber que vem de longe encontra hoje menos ouvintes que a informação sobre acontecimentos próximos. O saber que vinha de longe - do longe espacial das terras estranhas, ou do longe temporal contido na tradição -, dispunha de uma autoridade válida mesmo que não fosse controlável pela experiência. Mas a informação aspira a uma verificação imediata (BENJAMIN, 1994, p. 203). 
O homem do pós-guerra se esvazia em prol da informação, e mesmo o sujeito da contemporaneidade enquanto extensão daquele, se visto sob o viés das reflexões de Benjamin (embora localizadas em tempo específico), parece estar clivado, persegue a informação e esquece o saber escondido na narrativa da tradição, esse saber que nunca se entrega, que propõe uma reflexão e continua a perpetuar ecos que (re)contam, de diferentes maneiras, os feitos calcados na sabedoria e na experiência.

Respeitando o distanciamento temporal entre as reflexões de Walter Benjamin no que toca à figura do narrador e os desdobramentos dessa voz narrativa nos moldes da contemporaneidade, torna-se possível perceber que o abismo proposto pelas reflexões benjaminianas foi transposto. No "hoje" essa voz narrativa se desdobra em múltiplas possibilidades, haja vista a própria mutabilidade da narrativa. Como afirma Beatriz Sarlo: "quando a narração se separa do corpo, a experiência se separa de seu sentido" (SARLO, 2007, p.27), ou seja, com a experiência do período moderno, a morte do narrador benjaminiano não significa o fim, mas o advento de variadas formas de se narrar vinculadas à experiência subjetiva que se constrói no arcabouço moderno e pós-moderno das sociedades industrializadas do pós-guerra. Claro que essa leitura evidencia um problema: o texto benjaminiano pode ser lido como uma ingênua nostalgia de um passado idealizado não-industrial.

Paul Ricoeur (1995) tendo como ponto de partida a Poética de Aristóteles aponta para o conceito de mimese enquanto processor criador e não apenas imitativo, e, nesse sentido, atestando a evolução da narrativa e do ato de narrar no que toca a intriga, o desencadear da peripécia a ser narrada, vinculada ao seu próprio tempo. 0 autor reitera que:

Nada, portanto, exclui que a metamorfose da intriga encontre em algum lugar uma fronteira além da qual não é mais possível reconhecer o princípio formal de configuração temporal que faz da história contada uma história uma e completa. [...] Talvez seja necessário, apesar de tudo, confiar na exigência de concordância que estrutura, ainda hoje, a expectativa [...] e acreditar que novas formas narrativas, que ainda não sabemos denominar, estejam nascendo; elas atestarão que a função narrativa pode se metamorfosear, mas não morrer. Pois não temos qualquer ideia do que seria uma cultura em que não se soubesse mais o que significa narrar (RICOEUR, 1995, p.45-46).

Ricoeur rebate e a atualiza a reflexão apocalíptica de Benjamin no que toca o ato de narrar. $\mathrm{O}$ narrador e a narrativa se modificam, se atualizam, encontram formas de se representar no corpo da história do homem e sua relação com o mundo. Assim, embora o autor critique Benjamin, está de acordo com este ao inferir que as formas de narrar são historicamente condicionadas.

$\mathrm{Na}$ esteira de posicionamento crítico e atualização do pensamento benjaminiano, Jacques Rancière em A partilha do sensível: estética e politica (2005) se coloca em posição contrária à visão da modernidade enquanto momento no qual a arte deve se fechar em si mesma. Para o filósofo francês, há elementos no projeto modernista postulando a arte como um espaço aberto a todos, livre de hierarquias. Nesse sentido, também propõe um posicionamento no que se refere ao pensamento benjaminiano no que toca a relação das massas com as artes mecânicas. Rancière reitera que: 
O surgimento das massas na cena da história ou nas "novas" imagens não significa o vínculo entre a era das massas e a era da ciência e da técnica. Mas sim a lógica estética de um modo de visibilidade eu, por um lado, revoga as escalas de grandeza da tradição representativa e, por outro, revoga o modelo oratório da palavra em proveito da leitura dos signos sobre os corpos das coisas, dos homens e das sociedades (RANCIÈRE, 2005, p.50).

Rancière é extremamente lúcido ao apontar as formas que as artes representativas tomam na segunda metáde do século $X X$, mas é preciso lembrar que o próprio Badiou (2001), bem como Slavoj Žižek (2001), alertam para os perigos do discurso das pluralidades: baseado numa vocação democrática e inclusiva, ele acaba sendo apropriado pelo mercado para pulverizar quaisquer frentes significativas de resistência ao avanço desmesurado do capitalismo na virada do século XX para o XXI. O desafio da próxima década é retomar Marx sem recair em totalidades ingênuas ou perigosas. Para isso, o retorno criterioso ao pensamento da primeira geração da Escola de Frankfurt pode ser proveitoso e lançar luzes na produção contemporânea.

Com base no acima exposto, o pensamento benjaminiano em relação à arte literária e o narrar enquanto experiência que advém da tradição, se por um lado parece ultrapassado no âmbito da crítica e da teoria acerca da modernidade, da literatura, cinema e arte, por outro lado permanece enquanto elemento disseminador de reflexões. No campo da problemática estabelecida para esse artigo, a figura do narrador da tradição torna-se o pivô central para o desenrolar da análise de $O$ labirinto do Fauno, enquanto reinvenção do ato de contar histórias em detrimento da fantasia e do traumático evento histórico que marca a história de Ofélia, ou seja, 1944 e o pósguerra civil espanhola (1936-1939) sob regime franquista. Dessa forma, não procurando estabelecer uma leitura redutora do tema proposto, buscar-se-á a figura do narrador de Walter Benjamin na narrativa fílmica de Del Toro, não enquanto forma de se engessar a cultura que por si só revela-se mutável, mas na tentativa de se compreender o "acontecimento" proposto por Badiou por meio da trágica narrativa da pequena protagonista.

\section{3. ÀS PORTAS DO LABIRINTO: O RESGATE DA EXPERIÊNCIA.}

Como já afirmamos, cinema e literatura comungam semelhanças, são artes que, embora distintas, se afinam em muitos aspectos, estão em constante contato. Há de forma latente uma relação de caráter intertextual, as duas artes dialogam e encontram-se ainda mais próximas quanto ao aspecto estrutural. Corseuil afirma que a semelhança marcante entre literatura e cinema está na base estrutural e reitera que "essa estrutura é comum a todas as formas narrativas, independentemente de seu meio de expressão" (2009, p.372). Dessa forma, a narrativa é literatura por excelência e o cinema transporta essa narrativa para a arte em/do movimento, atestando o fato de que "há mudanças culturais que influenciam a forma através da qual certos gêneros se renovam ou incorporam mudanças, mas certos elementos da narrativa se fazem sempre presentes" (CORSEUIL, 2009, p.372), ou seja, há uma mudança precisamente estética e muito do que pertencia exclusivamente à literatura foi absorvido pelo 
cinema, evidenciando a relação intrínseca que existe entre homem e mundo, relação mútua de busca e reconhecimento, como também de renovação e adaptação às novas necessidades, ou seja, há no cinema uma certa imanência literária e esta sempre ecoa.

A magia, o encanto, o sombrio podem ser alguns dos adjetivos que, geralmente encontrados na literatura, estão explicitamente amarrados ao filme $O$ Labirinto do Fauno de Guillermo Del Toro, narrativa imersa na bruma do Fantástico que propõe o resgate e o sentido da existência pela perspectiva de uma criança. O filme está espacial e temporalmente fincado na Espanha de 1944, tempos de pós-guerra civil. Assim começa a história da menina Ofélia e sua relação com a mãe grávida, Carmen e o padrasto, Vidal, um cruel militar fascista.

Travando essa nova relação com o mundo dos adultos, Ofélia vai descobrir que, amarrado à sua realidade sombria, existe um mundo fantástico, que lhe será revelado pelo fauno, habitante de um labirinto escondido na floresta. Assim, pela voz de um narrador onisciente, a menina se descobre princesa de um mundo mágico nos subterrâneos e, para voltar a seu verdadeiro lar, precisa provar ser digna da realeza, antes da chegada da lua cheia. O filme do cineasta Guillermo Del Toro traça a trajetória de vida e morte dessa menina que, tendo de conviver com a ausência do pai, com a presença opressora do padrasto e com a guerra de resistência entre rebeldes e o exército franquista, vai buscar refugio na fantasia. Um mundo dividido: de um lado, a realidade cruel e despida de sentido da vida cotidiana e, de outro, a fantasia e a evasão para uma realidade pautada pelo Fantástico/Maravilhoso mágico e sombrio, no qual as pontas do destino se atam e o sofrimento toma o caráter de prova a ser vencida como expiação de erros passados.

\subsection{Percorrendo o labirinto}

O surgimento do romance, o advento da informação, as grandes mudanças sociais, o mal-estar da guerra, a incapacidade de intercambiar experiências, fatalmente são os algozes responsáveis pela morte e anulação do narrador. Segundo as reflexões de Benjamin, o narrador tradicional foi colocado em um quadro de relações antagônicas, no qual se vê em desvantagem, se comparado aos rápidos acontecimentos do mundo moderno. Seguindo essa mesma lógica, o cinema, por definição, torna o quadro ainda mais crítico, já que possui profundo parentesco com o romance. Se este não transmite a experiência, no sentido do saber acumulado pela tradição, apenas questiona o insólito sentido das coisas, aquele aparece como estandarte da cultura de massa que reverbera na contemporaneidade.

Ainda assim, Benjamin percebe que, em alguns momentos da narrativa romanesca, é possível ouvir ecos do grande narrador, essa voz que transpassa a narrativa e traz o resgate das coisas perdidas, revira o baú da memória e devolve ao universo da amnésia contemporânea, os ensinamentos e valores que se perderam no tempo. O tempo seguiu seu curso e a tradição foi apagada ou esquecida na memória do tempo e, como atesta Arnold Hauser (1998, p.992): "Dificilmente se encontrará hoje qualquer caminho praticável que conduza a uma arte primitiva e, no entanto, 
valiosa. A arte genuína, progressiva, criativa só pode significar hoje em dia uma arte complexa", ou seja, as artes e, por extensão, a própria literatura, estão se coadunando ao novo, estão em processo de renovação e adaptação e, por vezes, recorrem à tradição, tentando ajustar $o$ velho e o novo, travando um distanciamento/leitura dos resquícios do autêntico narrador. Uma renovação acionada pelo percurso do capitalismo e refratada pela Indústria Cultural, que não tem data marcada para chegar ao "veredicto" final, apenas é continuo e fragmentário, relativizando o absoluto já anteriormente pré-estabelecido.

Em O Labirinto do Fauno, há traços desse narrador da tradição, perceptíveis momentos em que sua voz não se perdeu. O filme, nos entremeios de sua fábula complexa, permite a subsistência desse narrador da sabedoria que, com a candura de suas palavras, acompanha a personagem Ofélia. Dotado de uma simplicidade natural ao contar, o narrador renuncia ao rebuscado, resgatando a própria forma do narrar benjaminiano. No contexto do filme, conforme assevera Corseuil, "o termo narrador não está necessariamente associado a uma individualidade, mas revela a presença de um agente organizador da diegese, ou seja, da narrativa" (2009, p. 374). Enquanto elemento estrutural, ele está presente em todos os planos da narração, pois coaduna o ato de narrar e as sequências de imagens, representando o início, o meio e o fim da história de forma harmônica. Abarca o todo na narrativa fílmica, assim como o narrador da tradição, que não individualiza; tem o dom de coletivizar, promovendo a participação de todos no todo.

Podemos retomar a afirmação de Benjamin (1994, p. 204): "Quanto maior a naturalidade com que o narrador renuncia às sutilezas psicológicas, mais facilmente a história se gravará na memória do ouvinte, mais completamente ela se assimilará à sua própria experiência e mais irresistivelmente ele cederá à inclinação de recontá-la um dia". Ou seja, o narrador tem em si a capacidade criadora e perpetuadora da experiência eternizada em suas palavras. Ele não apenas conta uma história, mas fará com que ela seja contada de novo, repetida e recuperada no tempo:

Conta-se que, há muito tempo... No Reino Subterrâneo, onde não existe mentira ou dor, vivia uma princesa que sonhava com o mundo dos humanos. Ela sonhava com o céu azul, a brisa suave e o sol brilhante. Um dia... Burlando toda a vigilância, a princesa escapou. Uma vez do lado de fora, a luz do sol a cegou... E apagou sua memória qualquer indício do passado. Ela se esqueceu de quem era e de onde vinha. Seu corpo sofreu com o frio, a doença e a dor. E, passados alguns anos, ela morreu. No entanto, seu pai, o Rei, sabia que a alma da princesa retornaria... Talvez em outro corpo... Em outro tempo e em outro lugar. Ele a esperaria até seu último alento... Até que o mundo parasse de girar (DEL TORO, Guillermo, 0 Labirinto do Fauno. São Paulo: Warner Bros, 2006. 1 DVD (118 min).

A história é contada por esse narrador em in ultima res: tudo passa a ser deflagrado a partir da morte da menina Ofélia, cometida pelo padrasto. O "eu" que fala dá o tom da fábula e, pelas poucas inferências que faz ao longo da diegese, é possível perceber todo o peso da sabedoria encarnado nos momentos em que se (re)simboliza a ideia da morte, figura constante em todo o filme, mas ironicamente distante do mundo real contemporâneo. Para Benjamin, a morte perdeu seu significado na contemporaneidade, tornou-se um signo esvaziado por meio de complexos e reiterados sistemas de negação, de distanciamento e de invisibilização. Seu referencial 
no mundo moderno é algo muito próximo do espetáculo, não possuindo ligação com o mundo dos vivos: a morte faz farte do lúdico, preenche as telas de cinema em histórias que o espectador presencia, indiferente, a morte - em geral, violenta - de centenas. Mas não são pessoas que morrem: são personagens interpretados por atores. Dessa forma, a palavra "morte" não encontra sinônimos nas palavras "medo", "certeza" ou "apreensão": é simplesmente banal e divertida, sua presença no contexto desse tipo de filme para grande público remete ao escape do cotidiano.

Mas a ideia de morte remete diretamente ao outro conceito, o de eterno, como assevera Benjamin:

A ideia da eternidade sempre teve na morte sua fonte mais rica. Se essa ideia está se atrofiando, temos que concluir que o rosto da morte deve ter assumido outro aspecto. Essa transformação é a mesma que reduziu a comunicabilidade da experiência à medida que a arte de narrar se extinguia (1994, p. 207).

O autor afirma que, da mesma forma que a tradição se perdeu, a noção ou conceito que as sociedades tinham de morte também se dissipou. A morte perdeu seu aspecto solene único como certeza absoluta e "no decorrer dos últimos séculos, podese observar que a idéia [sic] da morte vem perdendo, na consciência coletiva, sua onipresença e sua força de evocação" (BENJAMIN, 1994, p.207). E tal fato decorre da especialização, efeito do capital sobre a era burguesa, caracterizada por consumo e ostentação, simulacro e vazio. A sociedade desaprendeu o valor solene do momento de morte, "hoje, a morte é cada vez mais expulsa do universo dos vivos" (BENJAMIN, 1994, p. 207). Enquanto entidade imanente da tradição, assim como a narração, ela perdeu seu lugar de direito como única e absoluta certeza da vida, um fim sem data previamente marcada.

A passagem acima resgata a inserção do narrador em $O$ Labirinto do Fauno que, ao iniciar a narração pela morte, ignorando sua presença física, desde o princípio vai trazer em suas palavras um processo de (re)simbolização da própria ideia de do ato de morte, lições de vida e aprendizagem. Esse narrador ensina a morrer, se faz cronista da vida e passa a refletir sobre ela, projetando suas palavras em Ofélia que, tiranizada e oprimida, recupera novamente para o mundo dos vivos o significado esquecido da fatalidade da morte. A menina se torna emblemática da crueldade de estar no mundo, tentando entender as interrogações acerca da ausência, da tortura e da opressão. Assim, a noção de morte é atrelada à inocência, à fantasia de buscar algum tipo de evasão em mundo menos cruel que o instaurado pela estrutura aterradora da Espanha fascista de 1944

Mas será essa a leitura exigida pelo filme? Del Toro equilibra os espaços narrativos, inserindo nuances de cor e de trilha sonora para marcar ao espectador os pontos de travessia de Ofélia para o mundo encantado, mas permite que, em alguns momentos, elementos do mundo subterrâneo façam uma aparição na realidade, como na sequência em que a raiz de mandrágora que salvaria a mãe de Ofélia é destruída. O espectador não é deixado em paz na sua cadeira: ele é levado a compreender que, uma vez destruída a raiz, a mãe morrerá. A leitura lógica de "mera coincidência" é desarticulada através da adesão da focalização narrativa ao terror da menina, fazendo com que o espectador partilhe desse mesmo sentimento. 
O narrador, atrelando sua voz à narrativa visual dada pela sequência de imagens, passa a narrar morte e vida em caráter de "era uma vez", caminhando guiado pelo tom do conto de fadas (ou seja, atemporal), dando assim um caráter substancial e secular ao próprio ato de narrar, e isso é corroborado pelo fato de que:

O primeiro narrador verdadeiro é e continua sendo o narrador de conto de fadas. Esse conto sabia dar um bom conselho, quando ele era difícil de obter, e oferecer ajuda, em caso de emergência. Era a emergência provocada pelo mito. O conto de fadas nos revela as primeiras medidas tomadas pela humanidade para libertar-se do pesadelo mítico (BENJAMIN, 1994, p.215).

O nó do filme em questão não é fundado no mito, mas na inocência humana perdida. Se um herói aniquilando dezenas de inimigos provoca mórbido prazer no espectador do "filme de ação", a morte de uma criança com a qual o espectador foi levado a se identificar não funciona como espetáculo: ela precisa ser inserida num sistema simbólico para ser aceita. A morte não é justa: é certa. Tem, intrínseco a si mesma, o olhar devorador da imparcialidade. Assim, O Labirinto do Fauno traz na morte da protagonista, não o fim, mas o resgate da eternidade. Ofélia teria de passar por três provas para retornar ao seu reino encantado, e a última delas, insinua-se, seria sacrificar seu meio-irmão recém-nascido. Incapaz de fazer mal ao bebê, Ofélia é morta pelo padrasto, mas imediatamente sua morte é reintegrada pela voz do narrador: o teste final não era, de modo algum, derramar o sangue do bebê, mas justamente poupa-lo e escolher morrer no lugar dele. O altruísmo e a compaixão como valores que se sobrepõem à conservação da própria vida e à hierarquia aparente é a prova máxima do pertencimento da menina a esse mundo sem males e sem tristeza.

O narrador, assim, representa não só o aspecto intrínseco do filme, mas vai além das esferas estruturais: pela imagem e palavras, propõe um conselho acerca do que é preciso saber no que toca a vida ou o fim dela. O narrador abre a narrativa fílmica pela morte da personagem e termina pela vida:

\begin{abstract}
Diz-se que a princesa voltou para o reino de seu pai. E que reinou com justiça e bondade... por muitos séculos. Que foi amada por súditos... e que deixou pra trás... poucos rastros de sua existência no mundo... rastros estes visíveis somente àqueles... que sabem onde procurar (DEL TORO, Guillermo, O Labirinto do Fauno. São Paulo: Warner Bros, 2006. 1 DVD (118 min).
\end{abstract}

O narrador abre e fecha a história, reinterpreta a própria noção/conceito de morte e, ao terminar pela vida, que advém em outro plano, situada no imaginário de uma criança que se percebe em um mundo rodeado de faunos e fadas, labirintos e florestas encantadas, morrendo para se tornar uma história contada. Afirma Benjamin (1994, p.207):

\footnotetext{
"Ora, é no momento da morte que o saber e a sabedoria do homem e sobretudo sua existência vivida - e é dessa substância que são feitas as histórias - assumem pela primeira vez uma forma transmissível". Ofélia entra na história e precisa morrer para que a experiência não se perca, para que a sabedoria não seja um simulacro esvaziado, solto no tempo e no espaço. O significado para sua vida só pode ser encontrado e compreendido em presença da morte, é necessária uma reflexão acerca da morte para entender, então, o significado da vida.
} 


\begin{abstract}
Há, no último suspiro e posterior transcendência, um tom de amarga reflexão e pesar. O narrador, apresentando ao espectador Ofélia em sua brevidade, também empresta a ela sua serenidade e sabedoria do dom de narrar. A personagem, como que pressentindo seu destino, também conta histórias e resgata a resistência que só existe nas histórias fincadas na tradição, histórias com uma moral que nunca se esgota, dada a sua simplicidade profunda. Assim, a voz do narrador se personifica em Ofélia, que passa a tecer a narrativa em caráter de primeira pessoa, ou seja, a personagem assume $o$ ato narrativo sob uma perspectiva homodiegética:

Há muitos e muitos anos... Em um país longínquo e triste... Havia uma montanha enorme de pedras negras e ásperas. Ao cair da tarde... Em cima dessa montanha floria todas as noites, uma rosa que conferia imortalidade. Mas ninguém ousava se aproximar dela... Pois seus muitos espinhos eram venenosos. Entre os homens... Falava-se mais sobre o medo da morte e da dor... E nunca sobre a promessa de imortalidade. E, todas as tardes, a rosa murchava... Incapaz de conceder sua dádiva a ninguém... Esquecida e perdida no topo da montanha fria e escura... Sozinha até o fim dos tempos. (DEL TORO, Guillermo, O Labirinto do Fauno. São Paulo: Warner Bros, 2006. 1 DVD (118 min).
\end{abstract}

Assim como o narrador, Ofélia, ao assumir seu papel, assume também sua postura serena e sábia e, novamente recuperando a atmosfera dos contos de fadas, sedimenta a adesão ao universo maravilhoso, permitindo a reflexão no âmago das palavras que fluem na narrativa.

As palavras da menina, em essência, se mesclam às do narrador que as antecedeu. Ambos narradores usam referências postas num passado distante e recuperam o tempo e o espaço de eras imemoriais. Um é o narrador que transforma a morte de uma personagem em metamorfose para a transcendência e busca do resgate do significado esquecido acerca da morte; a outra, personificando o narrador e sendo legitimada pela experiência de morrer, atua e narra com uma sabedoria também vinda de tempos remotos e quase irrecuperáveis. Morrer, nesse sentido, tem a mesma validade da vida, ambos representam lados distintos e efêmeros do mesmo ato.

\title{
3.2. O fio de Ariadne: a morte de Ofélia pode ser lida como fidelidade ao evento?
}

O narrador do filme entretece a história de Ofélia entre dois planos distintos, o "realista" (guerrilha anti-Franco, Guerra Civil Espanhola) e o "fantástico" (narrativa mágico-maravilhosa da princesa renascida e de suas provações), deixando ao espectador a escolha de reduzir a leitura do filme entre algumas alternativas achatadoras (por exemplo, a de uma criança que se refugiava na fantasia para escapar à realidade cruel que a destruiu; ou a de uma mensagem espiritualista, reassegurando que há um sentido oculto para todos os sofrimentos e injustiças da vida) ou recepção do mesmo enquanto obra no limite, oscilando entre o otimismo da narrativa maravilhosa e o pessimismo sem volta da narrativa realista (e convém lembrar que, historicamente, a oposição a Franco foi massacrada e exterminada impiedosamente).

Como já vimos, Badiou entende o évenément como a emergência de uma nova ordem, um novo ponto de capitonê, que permite à visão humana reorganizar o mundo a partir de uma lógica que atravessa as alternativas lógicas até então consideradas possíveis. Desse modo, podemos postular que a travessia de Ofélia entre as duas narrativas, que the oferecem a morte com significados opostos (destruição sem sentido algum ou redenção vitoriosa) implica no surgimento de uma brecha para que 
ela opte entre a morte enquanto signo do desespero e da futilidade da luta contra a opressão ou a morte enquanto fidelidade ao Evento (escolhe-la em vez de matar o bebê marca sua fidelidade aos códigos éticos profundos da terra sem males e promove o resgate de sua posição no Mundo Subterrâneo).

Portanto, a morte de Ofelia assume significados opostos, dependendo do ponto de vista do espectador: no limite, é ele quem é convidado a tomar posição frente ao Evento proposto pela narrativa cinematográfica, devendo deliberar consigo mesmo e realizar sua leitura particular do filme. Claro que suas escolhas não se resumem a aceitar ou não a "realidade", no interior da narrativa ficcional, do mundo subterrâneo. O espectador é instado, através do duplo registro do filme (obtido, por exemplo, com a alternância da câmara "subjetiva", que acompanha a visão particular de Ofélia, fazendo com que nos identifiquemos com ela, e da câmara "objetiva", que assiste impessoalmente certos momentos), a hesitar perante a escolha. Muitos espectadores podem ter se incomodado mais com essa hesitação do que com a violência mostrada no registro "realista" da história. E é dessa hesitação que surge a leitura que propomos, entretecendo Benjamin com Badiou na estrutura dessa filme peculiar.

Se a voz do narrador - que, como já vimos, mistura-se à de Ofélia, insinuando dentro do contexto fílmico a continuidade da cadeia da tradição oral e seus múltiplos narradores - ressignifica a morte da menina, oferecendo a ela um sentido libertador, é preciso dar um passo adiante e considerar os valores implícitos escolhidos pela protagonista. Caso contrário, a ressignificação de sua morte parecerá um consolo tolo, uma recusa a enfrentar a crueza da vida e dos sofrimentos atrozes nela encontradosuma evasão estéril e alienadora, apenas. É preciso lembrar que Ofélia recebe instruções que deve cumprir fielmente a fim de recuperar seu estatuto de princesa. Ao desobedecer a última ordem, ela pensa, por momentos, estar se provando indigna de retornar ao reino de seus pais. Seu desespero é intenso. No entanto, ela agiu dentro do espírito das leis e valores que regem esse mesmo reino. A ordem de matar era a armadilha final, o teste para seu instinto e caráter. O mundo subterrâneo e sua ética rigorosa tornaram-se o Evento ao qual Ofélia foi fiel, mesmo quando acreditava traí-lo - e essa fidelidade é que reacendeu a narrativa mágico-maravilhosa da sua imortalidade.

É, portanto, a emergência da narrativa do mundo subterrâneo enquanto Evento que permite uma saída do labirinto, funcionando como fio de Ariadne para a heroína do filme. Guiada pela fidelidade, a existência dela continua, mesmo após ela exalar seu último suspiro na Espanha franquista.

Nessa leitura que propomos, o Evento de Badiou representa o nó que ata as duas pontas da morte da criança. O espectador, ao contrário do que não precisa mais "escolher" uma interpretação do filme entre a "realista" (Ofélia imaginando o mundo subterrâneo como escape de seu sofrimento) e a "mágica" (O mundo subterrâneo como metáfora da metafísica e de alguma ordem e sentido possíveis): ambas passam a integrar a proposta da escolha ética (o sacrifício de si) enquanto o único caminho possível para a imortalidade. Assim, mesmo que o mundo subterrâneo seja fruto da imaginação da menina, seu ato de recusar ferir o meio-irmão é o que a retira do plano da vida animal, puramente biológica, e a arremessa ao plano da Fidelidade que transcende a morte. O conselho do narrador benjaminiano, cujos ecos perpassam o filme, é o de escolher a fidelidade ao Evento. 


\section{CONSIDERAÇÕES FINAIS.}

É possível afirmar que, mesmo a morte não fazendo mais parte do cotidiano cultural das sociedades contemporâneas, seu valor pode ser reavaliado em filmes como o de Guillermo Del Toro, devido à sensibilidade e franca sabedoria com que alguns conceitos e valores são colocados em discussão. $O$ filme traz ao seio da sociedade a morte, não como espetáculo, mas como consequência da vida ou mesmo da fatalidade e injustiça diante da vida. A morte volta para casa e atesta sua sabedoria, pois como afirma Benjamin, "a morte é a sanção de tudo o que o narrador pode contar. É da morte que ele deriva sua autoridade" (1994, p. 208). Os narradores no filme em questão afirmam sua autoridade à medida que a vida se torna um fardo quase insuportável e a morte não é apresentada como alegoria, infinitamente distante da vida moderna, mas sim como a mais justa das presenças quando não há mais esperança.

Se, como afirma Benjamin (1994), a narrativa se perdeu com o advento do romance e da burguesia, devido à massificação da vida e à quebra da tradição, há momentos em que esse narrador aparece. De fato, é possível encontrar resquícios desse narrador em autores e obras da literatura romanesca, sejam elas no bojo do romance ou mesmo no seio das narrativas cinematográficas, já que literatura e cinema andam lado a lado. Quando esse narrador atravessa essas narrativas e pode ser identificado, fica patente o fato de que conhecimento, sabedoria e tradição estão além das esferas temporais e espaciais. O narrador de $O$ Labirinto do Fauno, se revela enquanto eco da sabedoria, é essa voz ressoa e provoca em quem toca a reflexão, bem como permite a reavaliação e a (re)simbolização de valores escamoteados nos tempos da economia de capital.

É preciso notar que esse conselho benjaminiano não deve ser apresentado como pacificador, integrante de um discurso apoiado na metafísica e que desobriga de lutar contra a injustiça no cotidiano, uma vez que essa injustiça seria "fatalmente" reequilibrada numa outra dimensão. Ao contrário: Ofélia só é resgatada porque resistiu aos valores franquistas. Sabemos que, num tempo futuro (e próximo) em relação ao tempo da ação do filme, os guerrilheiros serão massacrados; uns poucos conseguirão fugir para Portugal; a ditadura do Generalíssimo durará décadas e só acabará com a morte dele, em idade avançada. Ainda assim, ensina o filme, essa resistência não foi estúpida nem destituída de significado. Carmen, a guerrilheira que encarna a um só tempo o herói e a mãe substitutiva de Ofélia, vingará a menina partilhando da compaixão da mesma: em vez de matar o filho do sádico padrasto, anuncia que o criará sem que ele sequer saiba o nome do pai, interrompendo a orgulhosa cadeia de tradição de Vidal, que desejava que seu relógio fosse entregue ao menino junto com a narrativa da morte "heroica" do pai.

Interrupção da tradição militarista, hierarquizante, desumana e violenta; substituição desta por um conjunto de valores mais humanos, poupando o filho de Vidal e tentando encaminha-lo para uma vida nova; e a continuidade de Ofélia, seja na condição ideal de princesa do mundo subterrâneo, seja enquanto símbolo da inocência destruída pelo franquismo: esse é o conselho oferecido pelo narrador do filme de Del Toro, em nossa leitura. Conselho que está perfeitamente sintonizado tanto com o pensamento de Walter Benjamin quanto com o de Alain Badiou, e que faz sobressair o conteúdo crítico e libertário d'O Labirinto do Fauno. 


\section{REFERÊNCIAS}

AGAMBEN, Giorgio. O que é o contemporâneo? e outros ensaios. Trad. de Vinícius Nicastro Honesko. Chapecó: Argos, 2009.

BADIOU, Alain. Ethics: an essay on the understanding of Evil. Translated: Peter Hallward. New York/London: Verso, 2001.

São Paulo: a fundação do universalismo. Trad. de Wanda Caldeira Brant. São Paulo: Boitempo, 2009.

BARBOSA, João Alexandre. A modernidade do romance. In: A leitura do intervalo: ensaios críticos. São Paulo: Iluminuras, 1990. p. 119-131.

BENJAMIN, Walter. O narrador: considerações sobre a obra de Nikolai Leskov. In: Obras escolhidas: magia e técnica, arte e política. Trad. de Sérgio Paulo Rouanet. São Paulo: Brasiliense, 1994. (Obras Escolhidas; v. 1) p. 197-221.

BERMAN, Marshall. Tudo que é sólido desmancha no ar. Trad. de Carlos Felipe Moisés e Ana M. Ioratti. São Paulo: Companhia das Letras, 1986.

CORSEUIL, Anelise Reich. Literatura e cinema. In: BONNICI, Thomas; ZOLIN, Lúcia Osana (Org). Teoria literária: abordagens históricas e tendências contemporâneas. 3 ed. Maringá: Eduem, 2009. p. 369-378.

DEL TORO, Guillermo. O labirinto do Fauno. São Paulo: Warner Bros, 2006. 1 DVD (118 $\mathrm{min})$, son., color.

EAGLETON, Terry. As ilusões do pós-modernismo. Trad. de Elisabeth Barbosa. Rio de Janeiro: Jorge Zahar, 1998.

HAUSER, Arnold. História social da arte e da literatura. Trad. de Álvaro Cabral. São Paulo: Martins Fontes, 1998.

PALMA, Glória Maria (Org). Literatura e cinema: a demanda do Santo Graal \& Matrix. Eurico, o Presbítero \& A Máscara do Zorro. Bauru: Editora Alínea, 1998.

RANCIÈRE, Jacques. A partilha do sensível: estética e política. Trad. de Mônica Costa Netto. São Paulo: Exo experimental org.; Ed. 34, 2005.

RICOEUR, Paul. Tempo e narrativa: Tomo II. Trad. de Marina Appenzeller. Campinas: Papirus, 1995.

SARLO, Beatriz. Tempo passado: cultura da memória e guinada subjetiva. Trad. de Rosa Freire d'Aguiar. São Paulo: Companhia das Letras; Belo Horizonte: UFMG, 2007.

SCHOLLHAMMER, Karl Erik. Ficção brasileira contemporânea. Rio de Janeiro: Civilização Brasileira, 2009.

ŽIŽEK, Slavoj. Did somebody say totalitarianism?; five interventions in the misuse of a notion. New York barra London: Verso Books, 2001. 
Title: Echoes from the benjaminian narrator in the film El Laberinto del Fauno: a (re) signification of death by fidelity to Événement

Abstract: The benjaminian narrator is the presence that, doomed to emptying, takes part of a tradition already fragmented, it is the echo that, throughout time, instills values and regulates life concepts. Contemporary presents it in constant exile, corrupted its wisdom: living is trivial and dying does not produce or make sense anymore. In this context, literature and cinema turn the opposition of life and death into an opaque and relativized couplet: living is now and death becomes a plan sign, a simulacrum. This paper aims to reflect about the representation of death from the perspective of the narrator in O Laberinto del Fauno (2006), that is an omniscient voice which presents Ophelia, immersed in a world of oppression and shadow, character who has her perennial existence (re) symbolized in a moment that living means nothing and dying rescues values, turning it into immortality in the sense elaborated by Alain Badiou, that is fidelity to the Event (événement).

Keywords: The narrator. Cinema. Death. Contemporary. Walter Benjamin.

Recebido em: 06/09/2013. Aceito em 30/11/2013. 